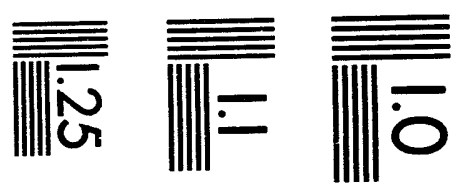

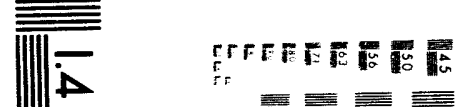

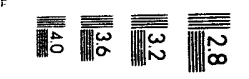

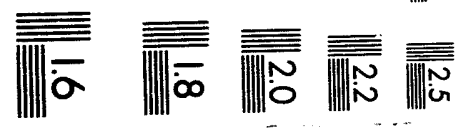



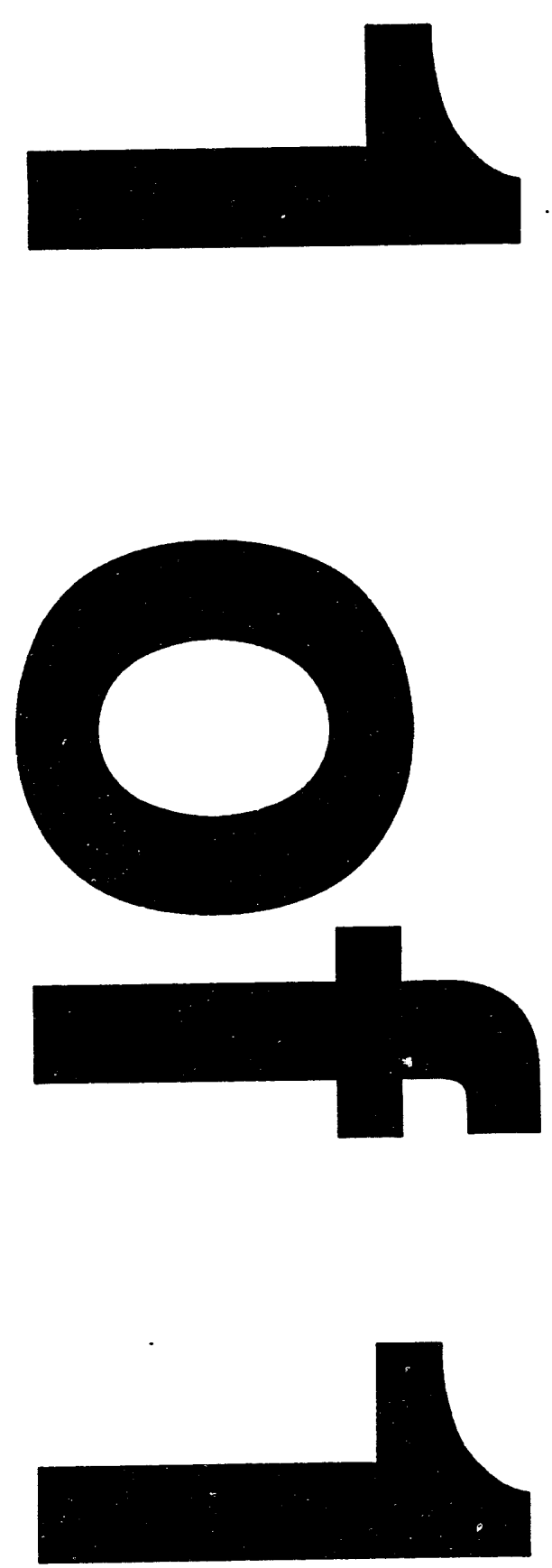


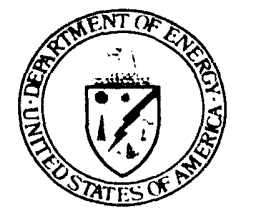

\title{
RCRA Post-Closure Permits
}

\begin{abstract}
BACKGROUND: The Resource Conservation and Recovery Act (RCRA) requires that hazardous waste management facilities operate in accordance with permits granted by the U.S. Environmental Protection Agency (EPA) or a State authorized to carry out the RCRA Subtitle $C$ program. Several categories of permits, including treatment, storage, and disposal permits; research, development and demonstration permits; post-closure permits; emergency permits; permits-by-rule; and trial burn and land treatment demonstration permits are issued under the RCRA Subtitle $\mathrm{C}$ program. This Information Brief focuses on post-closure permitting requirements under $40 \mathrm{CFR}$ 270.1(c).
\end{abstract}

STATUTE:

The Resource Conservation and Recovery Act (RCRA)

REGULATION:

40 CFR 264.110, 264.117 - 264.120, 265.110, 265.117 - 265.120, 270.1(c)

REFERENCES:
1. "Closure of Hazardous and Mixed Radioactive Waste Management Units at DOE Facilities," EH-231 RCRA Guidance Manual, DOE Office of Environmental Guidance, RCRACERCLA Division, June 1990.

2. "RCRA Closure and Post-Closure Plans," EH-231 RCRA Information Brief, EH231-009/1291, DOE Office of Environmental Guidance, RCRACERCLA Division, December 1991.

3. "RCRA Clean Closure Equivalency Demonstrations," EH-231 RCRA Information Brief, EH-231-
010/1291, DOE Office of Environmental Guidance, RCRA/CERCLA Division, December 1991.

4. "General Environmental Protection Program," DOE Order 5400.1, November 9, 1988.

5. "Radiation Protection of the Public and the Environment," DOE Order 5400.5, February 8, 1990.

6. "Radioactive Waste Management," DOE Order 5820.2A, September 26, 1988.

7. Memorandum on Post-Closure Permit Part B Requirements from the Director of the Permits and State Programs Division, U.S. Environmental Protection Agency, to Waste Management Division Directors, Regions I-X, U.S. Environmental Protection Agency, November 18, 1985.

8. "The Nation's Hazardous Waste Management Program at a Crossroads: The RCRA Implementation Study," Appendix D, Post-Closure Permitting Strategy, EPA/530-SW-90-069, July 1990.

\section{What is a post-closure permit?}

A RCRA post-closure permit details the requirements for the performance of post-closure care at facilities where wastes will remain in place after closure of a hazardous waste management unit. It also contains all of the conditions applicable to the permit such as its duration and recordkeeping requirements (40) CFR 27().32(a)). The post-closure permit serves as the basis for any enforcement actions deemed necessary by EPA or an authorized State during the post-closure period.

\section{What is post-closure care?}

Post-closure care encompasses all monitoring and maintenance activities that must be performed during the post-closure period by owners or operators of hazardous waste management facilities at which wastes will I main in place after closure 140) CFR 264.117 264.120, 265.117-265.120]. These facilities include:

All hazardous waste landfills, disposal surface impoundments, and land treatment units: and

Tank systems, waste piles, drip pads, and surface impoundments from which all waste residues and contaminated soils, materials. components, subsoils, and structures cannot be removed or decontaminated. (These facilities must. therefore, be closed as disposal units.)140 CFR 264.110, 265.110. 27() $.14(b)(13) \mid$

Monitoring is required to detect ground-water or soil contamination, leaks, or gas releases. Maintenance activities include all tasks necessary to ensure the integrity of hazardous waste containment systems and the functioning of monitoring equipment. Such activities include routine facility inspections, leachate management, continuation of hazardous waste degradation activities at land treatment facilities, and maintenance of waste containment systems, monitoring systems, and the security system.

Post-closure care activities must be described in written postclosure plans prepared in accordance with 40 CFR 264.118(b) or 40 CFR 265.118(c). Post-closure plans are incorporated into RCRA operating and post-closure permits. ("RCRA Closure and PostClosure Plans", EH-231 Information Brief EH-231-(0)9/1291, December 1991. provides more detailed information about RCRA postclosure plan requirements.)

Post-closure care activities at DOE's radioactive mixed waste (RMW) facilities must also be performed in accordance with applicable DOE orders. These include Order 54()0.5, "Radiation Protection of the Public and the Environment." and Order 5820.2A. "Radioactive Waste Management."

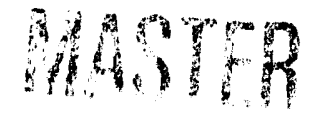

Printed on Recycled Paper 


\section{How long is the post-closure care period?}

EPA regulations require 30 years of post-closure care for each disposal unit, beginning after the completion of closure of the unit 140) CFR 264.117(a)(1), 265.117(a)(1)]. However, EPA Regional Administrators and State Directors have the authority to shorten or extend the post-closure care neriod. In addition, the owner/operator of the facility or any member of the public may petition a Regional Administrator or State Director to alter the length of the post-closure care period [40 CFR 124.5(a), 264.117(a)(2), 26.118(g), 270.41, 270.42 l. The length of the post-closure care period may be shortened if the regulator finds that a period of less than 30 years is sufficiently protective of human health and the environment, or extended if the regulator finds that a period of more than 30 years is necessary to protect human health and the environment (40) CFR 264.117(a)(2)(iii), $265.117(\mathrm{a})(2)(\mathrm{i}-\mathrm{ii}) \mid$.

An extension in the length of the post-closure care period is accomplished using procedures designated for a Class Two RCRA permit modification, while a reduction in the length of the post-closure care period requires a Class Three RCRA permit medification IAppendix I 10 4) CFR 270).42]. (Class Two modifications are used when changes have to be made at a facility to respond to variations in the type or quantity of waste managed. Class Three modifications are considered to substantially alter the facility or its operations. Because Class Three modifications are the most serious type of modifications, they require the greatest opportunity for public involvement.)

While under DOE control, facilities containing low-level radioactive or radioactive mixed waste must be maintained and monitored in accordance with the requirements of DOE Orders $54(\%) .1$, 5400.5 , and $5820.2 \mathrm{~A}$. The scope and level of monitoring activities must be based on site-specific analyses and monitoring plans and must include consideration of the facility's status (that is, whether the facility is operational or is in the post-closure care period.) Consistent with DOE Order 5820.2A, termination of monitoring and maintenance activities must be based on an analysis of site perfor.mance at the end of the institutional control period. This analysis must confirm that continued monitoring is not necessary to demonstrate compliance with DOE Orders $54(\%) .1$ and $54(0) .5$.

\section{Which facility owners or operators must obtain post- closure permits?}

Owners and operators of surface impoundments, landfills, land treatment units, and waste piles that received waste after July 26. 1982, or that certified closure (according to 40) CFR 265.115) after July 26, 1983, must obtain post-closure permits unless they demonstrate closure hy removal (i.e., "clean closure") as provided under 40) CFR 27().1(c)(5) and (6). Owners and operators of interim status units or facilities for which an operating permit is denied must perform closure in accordance with applicable 40) CFR 265 regulations and then obtain a post-closure permil |40) CFR 270).1(c)|.

\section{What information must be included in a post-closure permit application?}

40 CFR 270.1(c) requires that post-closure permits address all applicable 40 CFR 264 ground-water monitoring, unsaturated zone monitoring, corrective action, and post-closure care requirements. All information necessary to address these requirements must he submitted to the permitung authority to obtain a post-closure permit.

Regulations promulgated in 4() CFR 270.1. 3 and 270.14 describe the general information that must be included in RCRA Part $A$ and
Part B permit applications. These regulations, and specific Part B information requirements applicable to different types of hazardous waste management units [40 CFR 27(0.15 - 270.26], are applicable to both operating permit and post-closure permit applications. However, in response to a number of inquiries about the appropriatteness of many of these requirements (e.g., the requirement to provide information about the chemical and physical analyses of the waste to be handled at the facility 140 CFR 270.14(b)(2) i to the postclosure permitting process, the Director of EPA's RCRA Permits and State Programs Division has recommended that regulators only require the submission of information that is relevant to post-closure care activities (Memorandum on Post-Closure Permit Part B Requirements, November 18, 19851. For DOE facilities, 40 CFR requires that this information should. at a minimum, include:

$\square$ A copy of the post-closure inspection schedule $\mid \$ 270) .14(b)(5) \mid$;

a Floodplain information $\mid \$ 270.14($ b)(11)(iii-iv)|;

D A copy of the post-closure plan [\$270.14(h)(13)|;

$\square$ Documentation of the notice of former hazardous waste activity in the deed to the land $|\$ 27() .14(b)(14)|$;

4 Applicable ground-water monitoring data and information demonstrating compliance with requirements for detection monitoring, compliance monitoring. and corrective action $|\$ 27() .14(c)|$;

0 Information on solid waste management units and corrective action for releases from those units $\mid \$ 264.101\}$; and

Information on the potential for the public to be exposed to hazardous wastes or hazardous constituents from releases from hazardous waste management units $|\$ 270.1(0)(\mathrm{j})|$.

The permit modification procedures (40) (CFR 270). Subpart D) and expiration and continuation provisions |40 (CFR 27(), Subpart E] applicable to operating permits apply to post-closure permits as well.

\section{What is EPA's post-closure permitting strategy?}

As of July 1990, EPA estimated that they and authorized States still had to issue more than $1,6())$ post-closure permits and 850 storage and treatment operating permits. Many of these permits will have to include corrective action provisions. Given the enormous task of permitting and developing corrective action programs for this large number of facilities. EPA developed a post-closure permitting strategy which was first discussed in the RCRA Implementation Study. This strategy involves prioritizing facilities for permitting based on their environmental significance and evaluating whether the post-closure permitting process is an appropriate compliance mechanism for all facilities in the post-closure care period.

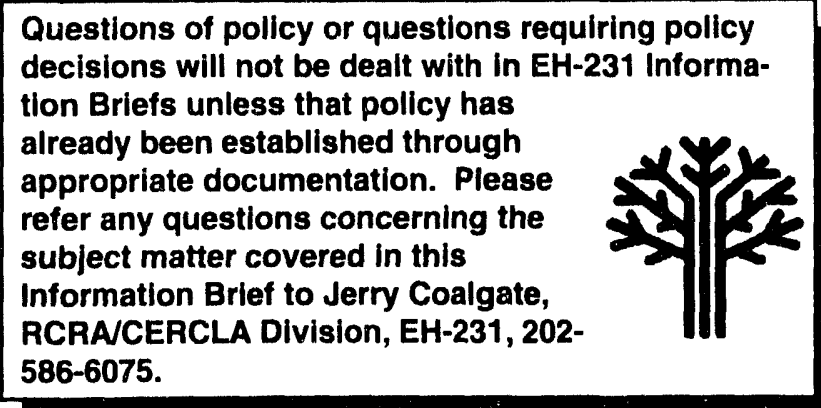



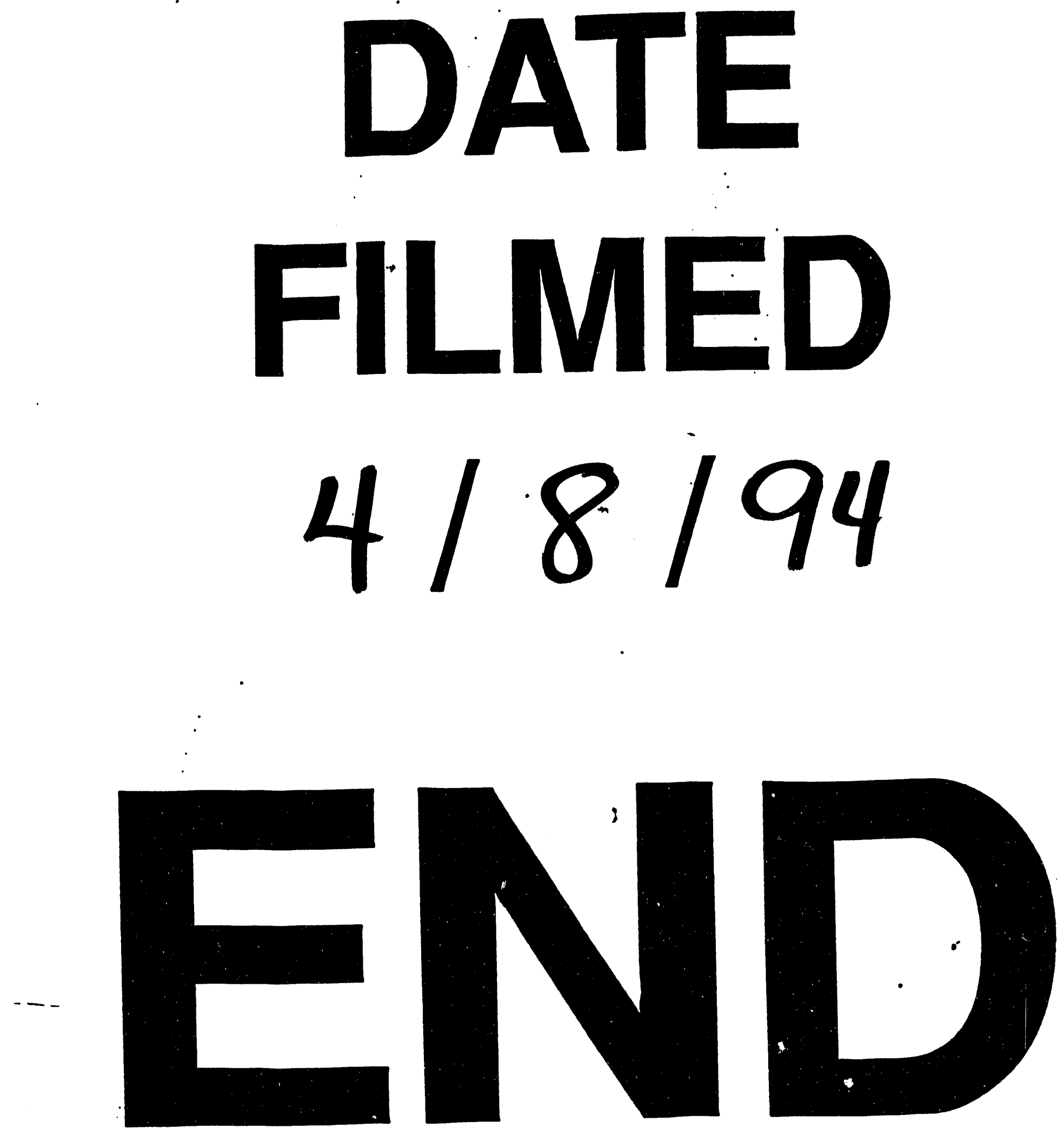
